\title{
Forgotten vaginal bees wax contraceptive insert in a 96 year-old woman presenting with tenesmus: a case report
}

\section{Tenesmus ile başvuran 96 yaşındaki bir kadında saptanan, unutulmuş vajinal kontrasepsiyon amaçlı balmumu insert: bir olgu sunumu}

\author{
Görker Sel ${ }^{1 *}\left(\mathbb{D}\right.$, Müge Harma $^{1}$ (D), Tuba Zengin ${ }^{1}$ (D), Dilara Özaydın ${ }^{1}$ (D), Mehmet Harma ${ }^{1}$ \\ 1 Zonguldak Bülent Ecevit University, Zonguldak, Turkey \\ * Corresponding author: Görker Sel E-mail: gorkersel@gmail.com ORCID: 0000-0001-8653-5687 \\ Received: 23 January 2019 Accepted: 18 May 2019
}

\begin{abstract}
Objective: Contraception prevents unintended pregnancy. Birth control has been used since ancient times. In this case report, we will discuss an old-fashioned method of contraception mimicking a cervical mass.

Case report: A 100-year-old, according to her relatives but according to her identity card 96-year-old, woman was admitted to Zonguldak Bülent Ecevit University Health Application and Research Center Gynecology Clinic with a complaint of tenesmus. Under general anesthesia gently, a $4 \times 4 \times 3 \mathrm{~cm}$ cervical mass was extracted. It was grey in color, round and composed of a firm material. It was a piece of beeswax that had been inserted probably 60 years ago, used for contraception.

Conclusion: In the Ottoman era, several plant roots, such as hibiscus root, were used as a as a contraceptive barrier method. However, some Turkish women still use traditional methods as seen in our patient. It is important to provide public education about safe contraceptive methods, especially before marriage to prevent unintended pregnancies.
\end{abstract}

Keywords: contraception, beeswax

() 2019 by the authors; licensee MEDITAGEM Ltd., Turkey. This article is an open access article distributed under the terms and conditions of the Creative Commons Attribution License (http://creativecommons.org/licenses/by/4.0/). 


\section{öz}

Amaç: Kontrasepsiyon istenmeyen gebeliği önler. Doğum kontrolü eski zamanlardan beri kullanılmaktadır. Bu olgu sunumunda servikal kitleyi taklit eden eski moda bir doğum kontrol yöntemini tartışacağız.

Olgu sunumu: Akrabalarına göre 100 yaşında, ancak kimlik kartına göre 96 yaşındaki, bir kadın tenesmus şikayeti ile Zonguldak Bülent Ecevit Üniversitesi Sağlık Uygulama ve Araştırma Hastanesi Jinekoloji Kliniğine kabul edildi. Genel anestezi altında kontrollü bir şekilde 4x4×3 cm servikal kitle ekstrakte edildi. Rengi gri, yuvarlak ve sert natürdeydi. Muhtemelen 60 yıl önce doğum kontrolü için kullanılan bir balmumu parçasıydı.

Sonuç: Osmanlı döneminde, hibiscus kökü gibi bazı bitki kökleri kontraseptif bariyer yöntemi olarak kullanılmıştır. Ancak bazı Türk kadınları hala hastamızda görüldüğü gibi geleneksel yöntemleri kullanmaktadır. İstenmeyen gebeliklerin önlenmesi için, özellikle evlilik öncesi, güvenli doğum kontrol yöntemleri hakkında halk eğitimi verilmesi önemlidir.

Anahtar kelimeler: kontrasepsiyon, balmumu

\section{INTRODUCTION}

Contraception provides control over the timing of pregnancy and or prevents unintended pregnancy [1]. Birth control has been used since ancient times, but effective and safe methods of birth control only became available in the $20^{\text {th }}$ century [2]. However, it is not always easy to access safe and modern methods of contraception especially in conservative rural areas. In this case report, we will discuss an old-fashioned method of contraception mimicking a cervical mass.

\section{CASE PRESENTATION}

A 100-year-old, according to her relatives but according to her identity card 96-year-old, woman was admitted to Zonguldak Bülent Ecevit University Health Application and Research Center Gynecology Clinic with a complaint of tenesmus. A gynecological physical examination revealed a cervical mass filling the vaginal cavity, a possible reason for the tenesmus. A rectal examination also revealed that the vaginal mass was exerting pressure on the rectum. Upon speculum examination, minimal vaginal discharge was detected, along with a cervical mass with dimensions of around $3 \times 3 \times 3 \mathrm{~cm}$. The mass was firmly attached to the vagina, and was impossible to move.

The patient did not have history of post-menopausal bleeding, nor gynecological operations. We planned to examine the mass under general anesthesia to avoid patient discomfort. After preoperative preparations were done, under general anesthesia, a vaginal examination was performed at the lithotomy position to make it possible to excise the cervical mass filling the vaginal cavity. Gently, a
$4 \times 4 \times 3 \mathrm{~cm}$ cervical mass was extracted with the use of ring forceps. It was grey in color, round and composed of a firm material (Figure 1). The operation was completed uneventfully.

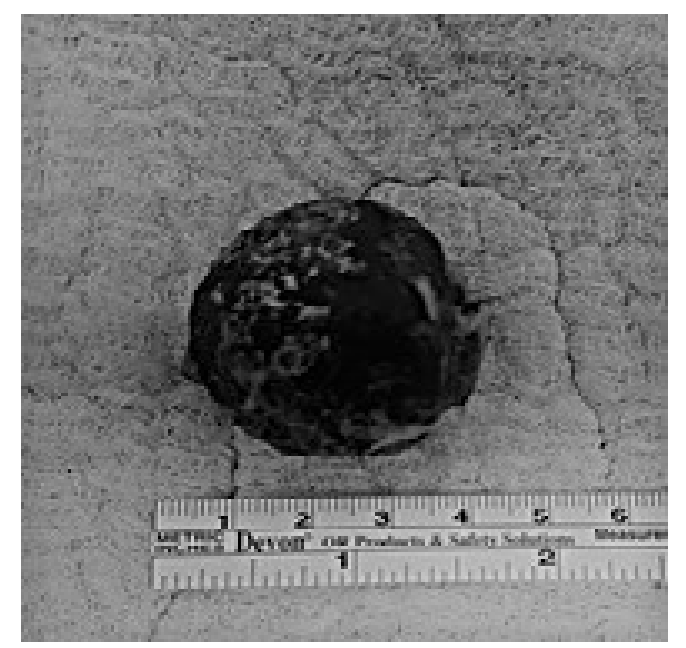

Figure 1. Extracted material, beeswax

The relatives of the patient explained the odd situation when they saw the foreign material that had been extracted from the vaginal cavity of the patient. It was a piece of beeswax that had been inserted a long time ago, probably 60 years ago, used for contraception. The pathologic examination also revealed this material as beeswax.

\section{DISCUSSION}

Contraceptive methods have been used since ancient times. The earliest known illustration of a man using a condom during sexual intercourse is painted on the wall of a cave in France, which has been found to be 12,000-15,000 years old [3]. The oldest excavated condoms were found in the foundations of Dudley Castle in England. They were made of 
animal gut and dated back to 1640 [3]. However, condoms at that time were generally used to prevent sexually transmitted diseases. By 1924, the condom was the most commonly prescribed method of birth control [4]. The Ebers Papyrus from 1550 BC and the Kahun Papyrus from 1850 BC have within them some of the earliest documented descriptions of birth control, i.e. the use of honey, acacia leaves and lint to be placed in the vagina to block sperm $[5,6]$. Throughout history, women have used various substances to block sperm passage. Vegetable seedpods were used in South Africa, plugs of grass and crushed roots were used in other parts of Africa, wads of seaweed, moss, and bamboo were used in Japan, China, and the South Sea Islands, and empty halves of pomegranates were used in ancient Greece [7]. In the 7th century BC, Sun Ssu-mo documented "thousands of gold contraceptive prescriptions" for women who no longer wanted to bear children. This prescription, which was supposed to induce sterility, was made of oil and quicksilver heated together for one day and taken orally [8].

Beeswax has also been used as a contraceptive barrier method, especially in Hungary and Germany [9]. From our patient, we learned that beeswax was also used as a contraceptive barrier method in rural areas of Turkey in 1950s. In the Ottoman era, several plant roots, such as hibiscus root, were used as a as a contraceptive barrier method [10]. However, some premenopausal Turkish women still use traditional methods like vaginal lavage, vaginal Aspirin ${ }^{\circledR}$ (acetylsalicylic acid tablets), and sponges soaked in fresh lemon juice or coke inserted deep into the vagina [11].

It is important to provide public education about safe contraceptive methods, especially before marriage to prevent unintended pregnancies. Even educated people may not know about safe contraceptive methods, become pregnant and unintentionally could exposed to teratogenic medicines or radiologic assessments in hospitals [12,13]. For instance, coitus interruptus still remains a popular method for contraception in Turkey.

\section{DECLARATION OF CONFLICT OF INTEREST}

The authors received no financial support for the research and/or authorship of this article. There is no conflict of interest.

\section{REFERENCES}

1. Peipert JF, Madden T, et al. "Preventing unintended pregnancies by providing no-cost contraception." Obstetrics and gynecology, 2012;120(6):1291.

2. Hanson SJ, Burke AE. Fertility Control: Contraception, Sterilization, and Abortion. In Hurt KJ, Guile MW, Bienstock JL, Fox HE, Wallach EE. The Johns Hopkins Manual of Gynecology and Obstetrics (4thed). Philadelphia, Wolters Kluwer Health/Lippincott Williams and Wilkins. 2010:382-395.

3. Parisot J, McCann B, Rudge G, Piggins B. Johnny come lately: a short history of the condom. 1987.

4. TONE, Andrea. Devices and desires: A history of contraceptives in America. Macmillan, 2002.

5. Cuomo A. Birth control. In O'Reilly, Andrea. Encyclopedia of motherhood. Thousand Oaks, Calif.: Sage Publications. 2010:121-126.

6. Lipsey RG, Carlaw K, Bekar C. Historical Record on the Control of Family Size. Economic Transformations: General Purpose Technologies and Long-Term Economic Growth. Oxford University Press. 2005: 335-40.

7. https://www.plannedparenthood.org/files/2613/9611/6 275/History_of_BC_Methods.pdf

8. Middleberg MI. Promoting reproductive security in developing countries. Springer. 2003: 4.

9. International Planned Parenthood Federation. Contraception at a Crossroads. 2008:11.

10. Ejder Apay S, Sakar T. A Different View to the Reproductive Health: Ottoman Period-Üreme Sağlığına Farklı Bir Bakış: Osmanlı Dönemi. Mersin Üniversitesi Tıp Fakültesi Lokman Hekim Tıp Tarihi ve Folklorik Tıp Dergisi, 2015;5(2):45-51.

11. Şahin NH, Kharbouch SB. Perimenopausal contraception in Turkish women: A cross-sectional study. BMC nursing, 2007;6(1):1.

12. Sel G, Küçük H, İbrahim Harma M, Harma M. Preferences of Pregnant Women for Continued Pregnancy Who Use Drugs with Teratogenic Risk in the First Trimester. Tıp Araş Arşivi, 2017;2(2):17-20. (doi: 10.5799/ahinjs.03.2017.02.007).

13. Sel G, Özün B, İbrahim Harma M, Harma M. Teratojenite Riski İçeren İyonlaştırıcı Radyasyona Maruz Kalan İlk Trimesterdeki Gebelerin, Gebeliklerinin Devamı Açısından Tercihleri, Batı Karadeniz Tıp Dergisi, 2018;2(1):139-43. (doi:10.29058/mjwbs.2018.1.3). 